\title{
Cryptococcus vishniacii sp. nov., an Antarctic Yeast
}

\author{
HELEN S. VISHNIAC $†$ AND WALTER P. HEMPFLING \\ Department of Biology, River Station, University of Rochester, Rochester, New York 14627
}

\begin{abstract}
Antarctic soil samples collected by W. V. Vishniac contained (among other microbes) 98 isolates of undescribed, imperfect yeasts. These isolates clustered as 16 biotypes of greater than $90 \%$ similarity to each other but less than $90 \%$ similarity to all previously described yeast species. We propose to include all such isolates in the new species Cryptococcus vishniacii, named in honor of $\mathrm{W}$. V. Vishniac. C. vishniacii grows at $4^{\circ} \mathrm{C}$ and below but not at $26^{\circ} \mathrm{C}$ and above, is cream-colored in mass, lacks pseudomycelia, is nonfermentative, produces "amylose," assimilates (at least) glucose, maltose, melezitose, trehalose, and xylose, and uses nitrate-N. The type strain, MTSW 304 Y268 (= ATCC 36649), does not grow at 21 to $22^{\circ} \mathrm{C}$ or above and assimilates (additionally) L-arabinose, D-glucuronic acid, raffinose, L-rhamnose (weakly), sucrose, succinate, and citrate.
\end{abstract}

The Dry Valleys of South Victoria Land (Antarctica) are the most extreme cold deserts known. It may be anticipated that this highly stressed environment, low in microbial abundance and diversity (6), contains unique populations. Microbiological examination of soil samples collected in the Dry Valleys by W. V. Vishniac and $Z$. Bowen in 1973 yielded 98 isolates of previously undescribed yeasts. A conservative interpretation of our phenetic studies places all of these isolates in a single new species for which we propose the name Cryptococcus vishniacii (in honor of Wolf Vladimir Vishniac, 1922-1973, who died while investigating the microbial biota of Antarctica).

\section{MATERIALS AND METHODS}

A list of some strains used in this study is given in Table 1. Although all 98 isolates were characterized, we have, in the interest of brevity, listed only a single isolate of each biotype from each soil sample. Isolation procedures are described elsewhere $(H$. S. Vishniac and W. P. Hempfling, J. Gen. Microbiol., in press).

Stock cultures were both incubated and held, at $4^{\circ} \mathrm{C}$, on slants of malt agar (Difco Laboratories, Detroit, Mich.) and GPY medium (glucose, $0.5 \%$; peptone, $0.5 \%$; yeast extract, $0.3 \%$ ) with or without phosphate buffer $\left(\mathrm{KP}_{\mathrm{i}} ; \mathrm{pH} 6.8,10 \mathrm{mM}\right)$. Unless otherwise specified, all concentrations were weight/volume percentages.

Standard methods currently in use in yeast taxonomy (12) were modified as required by available equipment, the sensitivity of some isolates to ammonium ions, and the characteristic low-temperature optima of these yeasts. Unless otherwise indicated, tests were performed at $10^{\circ} \mathrm{C}$, using Difco nitrogen-, carbon-, and vitamin-free yeast bases solidified with $1.8 \%$ agar

† Present address: Department of Cell, Molecular and Developmental Biology, Oklahoma State University, Stillwater, OK 74074.
(Difco) or made semisolid (in lieu of agitation of liquid cultures) with $0.1 \%$ agar or agarose (Sigma Chemical Co., Saint Louis, Mo. 63178). Optical densities or semisolid cultures were read at $660 \mathrm{~nm}$ in 1-cm-light-path cuvettes, using a Hitachi-Coleman Perkin-Elmer model 124 spectrophotometer.

Temperature tolerance and morphology (Dalmau plates) were studied by using malt agar, GPY agar, corn meal agar (Difco), and Y-1 (see below) agar.

Vitamin independence was examined by using culture vessels which had been heated to at least $400^{\circ} \mathrm{C}$ in a muffle furnace for a minimum of $2 \mathrm{~h}$. Agarose $(0.1 \%)$ did not interfere with detection of vitamin requirements of authentic strains. Results of tests with unshaken liquid media were consonant with those using (more optimal) semisolid media.

Sugars other than monosaccharides and D-glucuronic acid were sterilized by filtration through membrane filters $(0.22-\mu \mathrm{m}$ average pore size; Millipore Corp., Bedford, Mass.). Monosaccharides, sugar alcohols, and other organic acids were autoclaved separately as $10 \%$ solutions and added aseptically to prepared base. Soluble starch and inulin were autoclaved in the basal medium. Ethanol and decane were supplied by diffusion in closed containers to known users as well as to the test yeasts.

The D-glucose content of certain substrates was assayed by the glucose oxidase method (Glucostat Special, Worthington Biochemicals Corp., Freehold, N.J.); trehalose and raffinose did not contain detectable glucose (less than $0.005 \%$, wt/wt); sucrose contained $0.1 \%$ (wt/wt), and melezitose contained slightly over $1 \%(w t / w t)$. The agar used contained unidentified substances (staining brown with Gram iodine) which were cleared by some isolates. Appropriate controls indicated that neither substrate contamination with D-glucose nor agar contaminants allowed significant growth.

Substrate assimilation tests were performed by inoculating duplicate (with and without either the recommended amino acids of Wickerham or 10 to $20 \mathrm{mg}$ of Difco Casamino Acids per $100 \mathrm{ml}$ ) sets of dry agar plates with 14 isolates each, using a multipoint inoc- 
TABLE 1. Localities and sources for representative strains of Cryptococcus vishniacii

\begin{tabular}{|c|c|c|c|c|c|}
\hline Serial no. & & $\begin{array}{l}\text { boratory } \\
\text { /biotype }\end{array}$ & Name & Source & Habitat \\
\hline 1. & MYSW & $202 Y 252 / 12$ & $\begin{array}{l}\text { Cryptococcus vishnia- } \\
\text { cii }\end{array}$ & $\begin{array}{l}\text { Site 202: North flank of } \\
\text { Mt. Baldr }(6,220 \text { feet } \\
\text { [ca. } 1,896 \mathrm{~m}])\end{array}$ & $\begin{array}{l}\text { Soil (coarse, weathered doler- } \\
\text { ite gravel) }\end{array}$ \\
\hline 2. & & $202 \mathrm{Y} 347 / 4$ & & & \\
\hline 3. & & $202 Y 349 / 11$ & & & \\
\hline 4. & & $202 Y 375 / 13$ & & & \\
\hline 5. & & $302 Y 253 / 12$ & & $\begin{array}{l}\text { Site 302: Center Cliff, } \\
\text { near middle of east } \\
\text { slope, Mt. Baldr }(4,870 \\
\text { feet [ca. } 1,485 \mathrm{~m}])\end{array}$ & Soil (dolerite terrace) \\
\hline 6. & & $302 Y 259 / 14$ & & & \\
\hline 7. & & $302 Y 265 / 10$ & & & \\
\hline 8. & & $302 Y 309 / 4$ & & & \\
\hline 9. & & $302 Y 310 / 16$ & & & \\
\hline 10. & & $302 Y 312 / 5$ & & & \\
\hline 11. & & $303 \mathrm{Y} 200 / 3$ & & $\begin{array}{l}\text { Site 303: Foot of glacier } \\
(4,700 \text { feet [ca. } 1,433 \\
\text { m]) }\end{array}$ & Soil (dolerite moraine) \\
\hline 12. & & $303 \mathrm{Y} 202 / 6$ & & & \\
\hline 13. & & $303 Y 206 / 9$ & & & \\
\hline 14. & & $303 Y 216 / 1$ & & & \\
\hline 15. & & $303 Y 336 / 15$ & & & \\
\hline 16. & & $303 Y 338 / 8$ & & & \\
\hline 17. & & $303 Y 354 / 4$ & & & \\
\hline 18. & & $303 Y 364 / 7$ & & & \\
\hline 19. & & $303 Y 365 / 2$ & & & \\
\hline 20. & & $303 Y 368 / 13$ & & & \\
\hline 21. & & $304 Y 267 / 12$ & & $\begin{array}{l}\text { Site 304: Slope of Baldr's } \\
\text { Bathtub, } 250 \text { yards } \\
\text { (ca. } 229 \text { m) from its } \\
\text { center on course of } 17^{\circ} \\
\text { (4,660 feet [ca. } 1,421 \\
\text { m]) }\end{array}$ & Soil (sandstone, sand) \\
\hline 22. & & $304 \mathrm{Y} 268 / 7$ & (type) & & \\
\hline 23. & & $306 Y 212 / 6$ & & Site 306: Escarpment, & Soil (sandstone, sand) \\
\hline 24. & & $306 Y 250 / 12$ & & $\begin{array}{l}\text { northwest part of val- } \\
\text { ley, } 300 \text { yards (ca. } 183 \\
\text { m) from cliff }(4,750 \\
\text { feet [ca. } 1,448 \mathrm{~m} \text { ]) }\end{array}$ & \\
\hline 25. & & $309 Y 215 / 4$ & & $\begin{array}{l}\text { Site 309: Labyrinth, } \\
\text { south of Center Cliff, } \\
250 \text { feet (ca. } 76 \mathrm{~m} \text { ) } \\
\text { from frozen pond, and } \\
30 \text { feet (ca. } 9 \text { m) above }\end{array}$ & $\begin{array}{l}\text { Soil (mixed sand, basalt coi- } \\
\text { umns) }\end{array}$ \\
\hline & & & & $\begin{array}{l}(2,840 \text { feet [ca. } 866 \\
\mathrm{m}])\end{array}$ & \\
\hline 26. & & ATCC 12307 & $\begin{array}{l}\text { C. albidus, var. dif- } \\
\text { fluens (type) }\end{array}$ & & \\
\hline 27. & & ATCC 22461 & C. bhutanensis (type) & & \\
\hline 28. & & ATCC 22462 & $\begin{array}{l}\text { C. himalayensis } \\
\text { (type) }\end{array}$ & & \\
\hline 29. & & IAM 4963 & $\begin{array}{l}\text { C. himalayensis } \\
\text { (type) }\end{array}$ & & \\
\hline
\end{tabular}

${ }^{a}$ MYSW, W. P. Hempfling, Department of Biology, University of Rochester, Rochester, N.Y.; ATCC, American Type Culture Collection, Rockville, Md.; IAM, Institute of Applied Microbiology, University of Tokyo, Tokyo, Japan.

ulator (flat-tipped prongs $2 \mathrm{~mm}$ in diameter) charged from a welled template containing just slightly milky suspensions of the yeast isolates in sterile distilled water or basal medium. The inoculator was drawn forward slightly during inoculation to give a streak approximately 4 by $9 \mathrm{~mm}$. The absence of interactions between isolates was established by comparing the growth of selected isolates inoculated singly on slants with their growth on plates seeded by multiple inoculation.
Assimilation test plates were scored at about 7 days, 10 days, and 2,3 , and 4 weeks, after which they were flooded with Gram iodine to test for "amylose" production. Growth was judged " \pm " if visibly greater than the inoculum (a thin film viewed by oblique light), "+" if a complete but translucent layer, "++" if completely opaque to transmitted light from laboratory overhead lighting sources, or " +++ " if opaque and markedly overflowing the bounds of the inoculum streak. Only strong $(++$ or greater), rapid (within 2 
weeks), and unequivocal (continuous growth) responses were scored as positive; all other responses were scored as negative. Although minor variations in rapidity of growth occurred with variations in inoculum size and plate drymess, results scored as positive were replicable. Slow or weak responses, as well as some indeterminate responses which appeared to be dependent upon the presence of added amino acids, were not replicable.

The Wickerham media have failed to support the growth of some imperfect yeasts (3). These media, containing $38 \mathrm{mg}$-ions of ammonium ions per liter proved unsuitable for assimilation tests involving ammonium-sensitive yeasts during this study. The substrate responses of such isolates (and all other dubious results of testing by standard methods) were investigated by using medium Y-1. Medium Y-1 base contained $\mathrm{NH}_{4} \mathrm{NO}_{3}(1.25 \mathrm{mM}), \mathrm{MgSO}_{4} \cdot 7 \mathrm{H}_{2} \mathrm{O}(2.0 \mathrm{mM})$, potassium phosphate at $\mathrm{pH} 6.0(7 \mathrm{mM})$, and $10 \mathrm{ml}$ of a chelated trace metals solution per liter (14). Y-1, with substrates and vitamin supplements added aseptically as required, was used as a semisolid medium and was distributed in 10-ml amounts per 25-ml Erlenmeyer flasks. The responses obtained with this medium were reasonably replicable. We accordingly scored low growth (optical density at $660 \mathrm{~nm}$ of less than 1 after 10 days at $10^{\circ} \mathrm{C}$ fron an inoculum of ca. $10^{5}$ cells) as "positive (weak)." Y-1 media, with $\left(\mathrm{NH}_{4}\right)_{2} \mathrm{SO}_{4}(20 \mathrm{mM})$ substituted as the $\mathrm{N}$-source, were inhibitory to $C$. bhutanensis and to those strains of $C$. vishniacii listed (see Table 2 ) as ammonium sensitive.

Salt $(\mathrm{NaCl})$ tolerance was determined on $\mathrm{Y}-1$ agar with $11 \mathrm{mM}(0.2 \%)$ glucose. Since duration of incubation influences apparent tolerance, results were judged relative to the reported salt tolerances of the authentic cultures used. Comparative tests on GPY medium indicated distinctly lower salt tolerances, attributed to the possible salt content of the medium.

The characters used for single-linkage cluster analysis (modeled from reference 10) were: red- or orangecolored colonies; presence of pseudomycelia; fermentation of D-glucose and sucrose; assimilation of glucose, D-galactose, L-sorbose, sucrose, maltose, cellobiose, trehalose, lactose, melibiose, raffinose, melezitose, inulin, soluble starch, D-xylose, L-arabinose, D-arabinose, D-ribose, L-rhamnose, ethanol, glycerol, erythritol, ribitol (adonitol), galactitol (dulcitol), D-mannitol, Dglucitol (sorbitol), methyl $\alpha$-D-glucoside, salicin, lactate, succinate, citrate, inositol, and arbutin; growth with nitrate-N, ammonium-N, no vitamins, and 3,6 , and $9 \% \mathrm{NaCl}$; growth at $10,20,21$ to 22 (GPY agar), 26 , and $31^{\circ} \mathrm{C}$; liquefaction of gelatin; urease production; and "amylose" production. Characters of known species were taken from the report of Barnett and Pankhurst (1), in which definite values were assigned. When a character was given as "variable" or "undetermined," we used our own results for authentic strains. Our results for authentic strains were identical to those of Barnett and Pankhurst (using the data of the Centraalbureau voor Schimmelcultures) with the exception of some for C. himalayensis. Type cultures of $C$. himalayensis from both sources assimilated adonitol (ribitol) (Sigma), as do nearly all yeasts that utilize D-ribose (1). Neither culture assimilated lactose, nor was citrate or succinate assimilated. The assimi- lation of the latter acids is sometimes temperature dependent (Vishniac and Hempfling, in press); tests were conducted at 10,20 , and $23^{\circ} \mathrm{C}$. Our characterizations of $C$. vishniacii isolates will not necessarily be repeatable by others if the Wickerham ammoniumcontaining media are used indiscriminately or if tricarboxylic acid cycle substrates are tested at temperatures near the upper limit for growth. Evison and Rose (2) have shown the effects of stressing temperatures on tricarboxylic acid cycle functions in Candida A3E-2.

\section{RESULTS}

Latin diagnosis of Cryptococcus vishniacii sp. nov. Coloniae in agaro colore cremeo, aut politae et mucosae aut asperae et durae; in mediis liquidis difficiliter crescit, pelliculam haud, annulum exigue, et sedimentum lente formans. Crescit calore minus $4^{\circ} \mathrm{C}$, optime $10^{\circ} \mathrm{C}$ aut major, sed non $26^{\circ} \mathrm{C}$. Cellulae ovoideae $(4.5$ $\times 3 \mu \mathrm{m}$ ad $8.5 \times 5$ aut $9 \times 4.5 \mu \mathrm{m})$ aut subsphaeroideae ( $5.5 \mathrm{ad} 7 \mu \mathrm{m} \mathrm{d}$.) in diversas partes gemmant. Capsula exigua ad nulla. Nec ascosporas nec pseudomycelium vidi.

Nec glucosum nec sucrosum fermentat. Assimilat acidum citricum, acidum D-glucuronidum, acidum succinum, L-arabinosum, glucosum, maltosum, melezitosum, raffinosum, Lrhamnosum (lente), sucrosum, trehalosum xylosumque. Dum L-arabinosum, glucosum, sucrosum xylosumque assimilatur, amylosum formatum est. Non assimilat acidum lacticum, amylosum, D-arabinosum, cellobiosum, decanum, erythritolum, ethanolum, galactitolum (dulcitolum), D-galactosum, D-glucitolum (sorbitolum), glycerolum, inositolum, inulinum, lactosum, D-mannitolum, melibiosum, methyl- $\alpha$-Dglucosidum, ribitolum (adonitolum), D-ribosum, salicinum nec L-sorbosum. Crescit cum nitrato; crescit sine vitaminis. Gelatinum et urea non finduntur.

Typus 304 Y268 e solo, Mons Baldr 4660 p.

Differt in varietas quae sucrosum raffinosumque non assimilant aut $\mathrm{L}$-arabinosum aut $\mathrm{L}$ rhamnosum non assimilant aut cellobiosum salicinumque assimilant. Effectus in methyl- $\alpha$-Dglucosidum, acidum citricum succinumque, ammonum, vitamines, natrium chloridum, caloremque et mutantem.

Standard description of Cryptococcus vishniacii sp. nov. This species is typified by isolate 304Y268 isolated from soil (sandstone, sand) from Mt. Baldr (at 4,660 feet [ca. 1,421 m]) South Victoria Land, Antarctica, and deposited in the American Type Culture Collection (Rockville, Md.) as ATCC 36649. The species is considered to include all isolates showing greater than $90 \%$ similarity to the type isolate.

Isolate $304 \mathrm{Y} 268$ possesses all of the common characters of the species: colonies on agar are 
TABLE 2. Characteristics of Cryptococcus vishniacii biotypes ${ }^{a}$

\begin{tabular}{|c|c|c|c|c|c|c|c|c|c|c|c|c|}
\hline \multirow[b]{2}{*}{ 总 } & \multirow[b]{2}{*}{ 弯 } & \multirow[b]{2}{*}{ 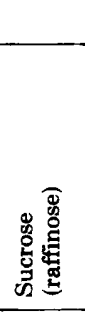 } & \multicolumn{5}{|c|}{ Assimilation of: } & \multicolumn{4}{|c|}{ Growth with: } & \multirow[b]{2}{*}{$\begin{array}{c}\text { Growth at } \\
\text { various } \\
\text { temp }\end{array}$} \\
\hline & & & 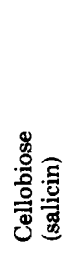 & 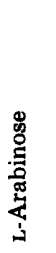 & 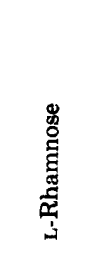 & 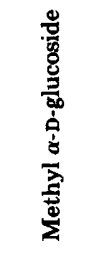 & 营 & 苞 & 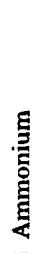 & $\begin{array}{l}\text { 蛋 } \\
\text { 蛋 } \\
\text { 之o }\end{array}$ & 己ु & \\
\hline 1. & $303 Y 216$ & $\begin{array}{c}0 \\
(0)\end{array}$ & $\begin{array}{c}0 \\
(0)\end{array}$ & 0 & $\begin{array}{c}+ \\
\text { (weak) }\end{array}$ & 0 & 0 & + & $\mathbf{v}$ & + & 2 & 2 \\
\hline 2. & $303 Y 365$ & $\begin{array}{c}0 \\
(0)\end{array}$ & $\begin{array}{c}0 \\
(0)\end{array}$ & 0 & $\begin{array}{c}+ \\
\text { (weak) }\end{array}$ & 0 & 0 & + & + & + & 2 & $(\geq 2)$ \\
\hline 3. & $303 Y 200$ & $\stackrel{+}{(+)}$ & $\begin{array}{c}0 \\
(0)\end{array}$ & 0 & $\begin{array}{c}+ \\
\text { (weak) }\end{array}$ & $\begin{array}{c}+ \\
\text { (weak) }\end{array}$ & 0 & + & + & + & 2 & 2 \\
\hline 4. & $\begin{array}{l}309 Y 215 \\
303 Y 354 \\
302 Y 309 \\
202 Y 347\end{array}$ & $\begin{array}{r}+\mathbf{a} \\
(+)\end{array}$ & $\begin{array}{c}0 \\
(0)\end{array}$ & 0 & $\begin{array}{c}+ \\
\text { (weak) }\end{array}$ & 0 & 0 & + & + & + & 2 & 2 \\
\hline 5. & $302 Y 312$ & $\begin{array}{c}+ \\
(+)\end{array}$ & $\begin{array}{c}0 \\
(0)\end{array}$ & 0 & $\underset{\text { (weak) }}{+}$ & 0 & 0 & + & I & + & 2 & 2 \\
\hline 6. & $\begin{array}{l}306 Y 212 \\
303 Y 202\end{array}$ & $\begin{array}{c}+a \\
(+)\end{array}$ & $\begin{array}{c}0 \\
(0)\end{array}$ & 0 & $\begin{array}{c}+ \\
\text { (weak) }\end{array}$ & 0 & 0 & 0 & + & + & 2 & 2 \\
\hline 7. & $\begin{array}{l}304 Y_{268^{b}} \\
303 Y 364\end{array}$ & $\begin{array}{l}+a \\
(+)\end{array}$ & $\begin{array}{c}0 \\
(0)\end{array}$ & $+\mathbf{a}$ & $\begin{array}{c}+ \\
\text { (weak) }\end{array}$ & 0 & + & + & + & + & 2 & 1 \\
\hline 8. & $303 Y 338$ & $\begin{array}{l}+a \\
(+)\end{array}$ & $\begin{array}{c}0 \\
(0)\end{array}$ & $+a$ & $\begin{array}{c}+ \\
\text { (weak) }\end{array}$ & 0 & + & + & + & + & 2 & $(\geq 2)$ \\
\hline 9. & $303 Y 206$ & $\stackrel{+}{+}$ & $\stackrel{+}{(+)}$ & 0 & 0 & + & + & + & + & + & 1 & 3 \\
\hline 10. & $302 Y 265$ & $\begin{array}{c}+a \\
(+)\end{array}$ & $\begin{array}{c}+ \\
(+)\end{array}$ & $+\mathbf{a}$ & 0 & $+\mathbf{a}$ & + & + & + & + & 2 & 4 \\
\hline 11. & $202 Y 349$ & $\stackrel{+}{(+)}$ & $\stackrel{+}{(+)}$ & $+\mathbf{a}$ & 0 & $+\mathbf{a}$ & + & + & + & $\mathbf{s}$ & 2 & $(\geq 3)$ \\
\hline 12. & $\begin{array}{l}202 Y 252 \\
302 Y 253 \\
303 Y 267 \\
306 Y 250\end{array}$ & $\stackrel{+}{(+)}$ & $\stackrel{+}{(+)}$ & $+\mathbf{a}$ & 0 & + & + & 0 & + & + & 2 & 3 \\
\hline 13. & $\begin{array}{l}202 Y 357 \\
303 Y 368\end{array}$ & $\stackrel{+}{+}$ & $\stackrel{+}{(+)}$ & $+a$ & 0 & + & + & 0 & I & + & 2 & $(\geq 3)$ \\
\hline 14. & $302 Y 259$ & $\begin{array}{l}+a \\
(+)\end{array}$ & $\stackrel{+}{(+)}$ & $+a$ & 0 & 0 & $\begin{array}{c}+ \\
\text { (weak) }\end{array}$ & 0 & + & + & 2 & 4 \\
\hline 15. & $303 Y 336$ & $\begin{array}{l}+\mathbf{a} \\
(+)\end{array}$ & $\begin{array}{c}0 \\
(+)\end{array}$ & $+\mathbf{a}$ & $\mathbf{0}$ & + & 0 & 0 & + & + & 2 & $(\geq 2)$ \\
\hline 16. & $302 Y 310$ & $\begin{array}{c}+a \\
(+)\end{array}$ & $\stackrel{+}{(+)}$ & $+a$ & + & + & + & + & + & + & 2 & 4 \\
\hline
\end{tabular}

${ }^{a}+$, Positive; +a, positive and amylose produced; 0 , negative; v, variably inhibited; I, inhibited; s, stimulated by vitamin supplement. Results for sucrose (raffinose) and cellobiose (salicin) are so coupled since they were (with one exception) identical. This similarity may depend upon the activity of a single enzyme in each case. The apparent exception (biotype 15) may resemble Rhodoturula minuta in possessing a $\beta$-glucosidase more actively hydrolyzing salicin than cellobiose (1). Growth in the presence of $\mathrm{NaCl}$ was scored as 1 where growth at $3 \%$ was greater than that of $C$. albidus var. diffluens, but growth at $6 \%$ was equally absent and was scored as 2 where growth at $6 \%$ approximately equalled that of $C$. bhutanensis (weak and delayed: Goto and Sugiyama [5] recorded growth at $6 \%$ but not growth at $9 \%$ ) but not that of $C$. himalayensis (scanty growth at $9 \%$ : Goto and Sugiyama [5]). Temperature responses were complicated by variation in the array of temperatures available at different times during our study. They were scored as 1 for optimal growth at $10^{\circ} \mathrm{C}$ (rather than 4 or $20^{\circ} \mathrm{C}$ ), 2 for optimal growth at $20^{\circ} \mathrm{C}$ (rather than $10^{\circ} \mathrm{C}$ ) but no growth at temperatures of 21 to $22^{\circ} \mathrm{C}, \geq 2$ for optimal growth at $20^{\circ} \mathrm{C}$ but no growth at 23 to $24^{\circ} \mathrm{C}$ when temperatures of 21 to $22^{\circ} \mathrm{C}$ were not available for testing, 3 for growth on corn meal agar (an impoverished medium for these isolates) but not on GPY agar at 21 to $22^{\circ} \mathrm{C}$, 4 for growth on GPY agar at 21 to $22^{\circ} \mathrm{C}$, and $\geq 3$ for growth on Y-1 agar at 23 to $24^{\circ} \mathrm{C}$.

bype species. 
cream colored, either glistening and mucoid (GPY agar) or tough and granular (malt extract agar) in appearance and texture. Growth in liquid media is limited; no pellicle is formed, a scanty annulus and slowly produced sediment giving the only evidence of growth. Cells are ovoid ( 4.5 by $3 \mu \mathrm{m}$ to 8.5 by 5 or 9 by $4.5 \mu \mathrm{m}$ ) or subspherical (5.5 to $7 \mu \mathrm{m}$ in diameter) with a scanty $(1 \mu \mathrm{m})$ to no visible capsule. Budding is usually but not necessarily polar. Pseudomycelia are not formed and ascospores were not observed. Fermentation does not occur. Glucose, maltose, melezitose, trehalose, and xylose are assimilated, and D-arabinose, decane, erythritol, ethanol, galactitol (dulcitol), galactose, D-glucitol (sorbitol), glycerol, inositol, inulin, lactic acid, lactose, D-mannitol, melibiose, ribitol (adonitol), D-ribose, soluble starch, and sorbose are not assimilated. Nitrate- $\mathrm{N}$ is utilized, but neither gelatin nor urea is split. "Amylose" is produced during growth on glucose or xylose. There is no growth at $26^{\circ} \mathrm{C}$.

In addition to these characters common to all isolates, $304 \mathrm{Y} 268$ assimilates L-arabinose and sucrose with amylose production and assimilates citric acid, D-glucuronic acid, raffinose, L-rhamnose (weakly), and succinic acid but not cellobiose or salicin. All biotypes of $C$. vishniacii assimilate D-glucuronic acid and fail to assimilate D-glucosamine. 304Y268 grows well on the Wickerham media, does not require vitamins, grows about as well as $C$. bhutanensis in the presence of $6 \% \mathrm{NaCl}$, and has an optimal temperature for growth nearest to $10^{\circ} \mathrm{C}$ (of the available temperatures), growing well at $4^{\circ} \mathrm{C}$, poorly at $20^{\circ} \mathrm{C}$, and not at all at 21 to $22^{\circ} \mathrm{C}$.

Character differences of typical isolates belonging to biotypes with greater than $90 \%$ similarity to biotype 7 (304Y268) are given in Table 2. A similarity dendrogram including these isolates and the nearest previously described species is given as Fig. 1.

\section{DISCUSSION}

Generic assignment. The history of the genus Cryptococcus has been discussed by Lodder (8), Phaff and Fell (9), and Kreger-van Rij (7). Cryptococcus is an anascosporogenous genus, lacking pseudomycelia, defined by a complex of additional characters which has included the absence of red or orange colonies, absence of fermentation, production of starchlike compounds (amylose) at low $\mathrm{pH}$, and inositol assimilation. Golubev et al.(4) have suggested that Dglucuronic acid assimilation is diagnostically equivalent to the utilization of myo-inositol, the character considered decisive by some workers

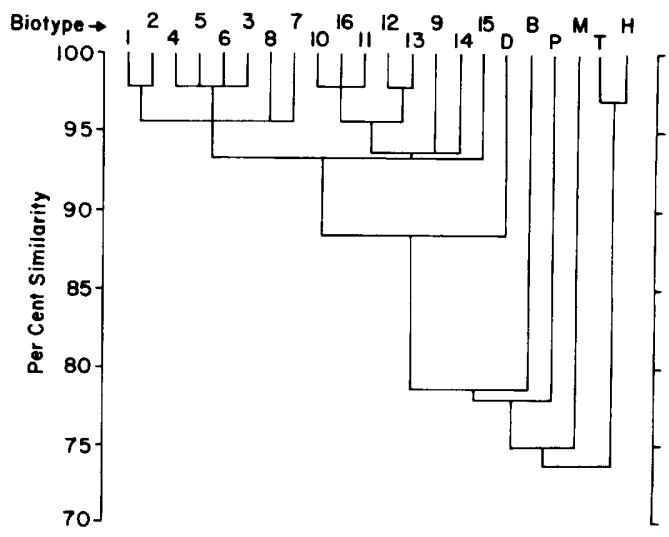

FIG. 1. Percent similarity of biotypes of Cryptococcus vishniacii and the most similar yeast species. $D$, $C$. albidus var. diffluens; $B, C$. bhutanensis; $P, C$. (T.) pignaliae; $M, C$. (T.) mannitofaciens; $T, C$. terreus; $H$, C. himalayensis. C. vishniacii biotypes clustered at $93.5 \%$.

(9). If the diagnosis of Cryptococcus is amended by this suggestion, $C$. vishniacii meets all of the historical criteria for inclusion in this genus.

Many systematic microbiologists would prefer to follow van Niel (13) in refusing to give any single physiological character generic weight. Our generic assignment is based upon numerical analysis of the similarity between our individual biotypes and all described species of yeasts (of whatever genus) as tabulated by Barnett and Pankhurst (1). The known yeasts most similar to C. vishniacii include species of Cryptococcus (C. albidus var. diffluens, C. bhutanensis, $C$. himalayensis, and C. terreus) and of Candida (Torulopsis) (Candida mannitofaciens and Candida pignaliae), but the closest linkage is to other species of Cryptococcus (Fig. 1.). C. bhutanensis Goto and Sugiyama (5), like C. vishniacii, fails to assimilate inositol but does assimilate D-glucuronic acid (4).

Specific assignment. C. vishniacii differs from C. albidus var. diffluens ATCC 12307 in colonial morphology, lacking the slimy translucent appearance and cohesion of the latter; in lower cardinal temperatures; in greater salt tolerance; in lack of urease; in ability to grow in vitamin-free media; and in failure to assimilate inositol. The type isolate of $C$. vishniacii also differs in inability to assimilate cellobiose.

C. vishniacii resembles $C$. bhutanensis in colonial morphology and degree of encapsulation as well as in failure to assimilate inositol, but differs from the latter in slightly lower temperature limits (C. bhutanensis grew under our conditions at 26 to $27^{\circ} \mathrm{C}$ but not at $31^{\circ} \mathrm{C}$ ) and in 
failure to assimilate mannitol, soluble starch, sorbose, sorbitol (glucitol), and D-arabinose or to require vitamin supplements $C$. bhutanensis fails to produce amylose consistently on Wickerham media but does so on media containing lower ammonium levels and suitable substrates.

The phenetic characterization of imperfect yeasts provides an inadequate measure of genetic dissimilarity. A single difference in substrate utilization may be associated with a relatively wide difference in guanine-plus-cytosine composition (11). A comparison of guanine-pluscytosine composition in the biotypes of $C$. vishniacii might well indicate that they represent independently derived genotypes converging in an uniquely stressed environment. In the absence of such data, the erection of a single species appears appropriately conservative.

\section{ACKNOWLEDGMENTS}

This study was supported by a grant (NGR-33-019-002) from the Office of Space Sciences, National Aeronautics and Space Administration, Washington, D.C. H.S.V. is grateful for support as Florence B. Seibert Fellow of the American Association of University Women during part of this study.

We wish to thank K. Yamasato and the Culture Collection of the Institute of Applied Microbiology of the University of Tokyo for $C$. himalayensis IAM 4963, R. R. Colwell for reagents, $H$. J. Phaff for advice, and the following members of the MYSW laboratory who participated in isolation and analysis: T. Kurtz, P.L.R. Farrell, C. Rice, and I. Uydess. We are indebted to L. Rodrigues de Miranda of the Centraalbureau voor Schimmelcultures for stimulating discussions.

\section{REPRINT REQUESTS}

Address reprint requests to: Dr. H. S. Vishniac, Department of Cell, Molecular and Developmental Biology, Oklahoma State University, Stillwater, OK 74074.

\section{ADDENDUM}

All biotypes of $C$. vishniacii assimilate D-glucuronic acid and fail to assimilate D-glucosamine.

\section{LITERATURE CITED}

1. Barnett, J. A., and R. J. Pankhurst. 1974. A new key to the yeasts. North Holland Publishing Co., Amsterdam.

2. Evison, L. M., and A. H. Rose. 1965. A comparative study on the biochemical basis of the maximum temperatures for growth in three psychrophilic microorganisms. J. Gen. Microbiol. 40:349-364.

3. Fell, J. W. 1974. Distribution of yeasts in the water masses of the southern oceans, p. 510-523. In R. R. Colwell and R. Y. Morita (ed.), Effect of the ocean environment on microbial activities. University Park Press, Baltimore.

4. Golubev, V. I., O. N. Okunev, and N. V. Vdovina. 1974. Assimilation of i-inositol by yeasts as a diagnostic character. Mikrobiologiya (English transl.) 43:890-893.

5. Goto, S., and J. Sugiyama. 1970. Studies on Himalayan yeasts and moulds. IV. Several asporogenous yeasts including two new taxa of Cryptococcus. Can. J. Bot. 48:2097-2101.

6. Horowitz, N. H., R. E. Cameron, and J. S. Hubbard. 1972. Microbiology of the Dry Valleys of Antarctica. Science 176:244-245.

7. Kreger-van-Rij, N. J. W. 1969. Taxonomy and systematics of yeasts, p. 5-78. In A. H. Rose and J. S. Harrison (ed.) The yeasts, vol. 1, Academic Press Inc., New York.

8. Lodder, J. 1970. General classification of the yeasts, p. 133. In J. Lodder (ed.), The yeasts-a taxonomic study. North Holland Publishing Co., Amsterdam.

9. Phaff, H. J., and J. W. Fell. 1970. Cryptococcus Kutzing emend. Phaff et Spencer, p. 1088-1091. In J. Lodder (ed.), The yeasts-a taxonomic study. North Holland Publishing Co., Amsterdam.

10. Sneath, P. H. 1972. Computer taxonomy, p. 29-98. In J. R. Norris et al., Methods in microbiology, vol. 7A. Academic Press Inc., New York.

11. Starmer, W. T., H. J. Phaff, M. Miranda, and M. W. Miller. 1978. Pichia cactophila, a new species of yeast found in decaying tissue of cacti. Int. J. Syst. Bacteriol. 28:318-325.

12. van der Walt, J. P. 1970. Criteria and methods used in classification, p. 34-113. In J. Lodder (ed.), The yeastsa taxonomic study. North Holland Publishing Co., Amsterdam.

13. van Niel, C. B. 1971 . The yeasts-a taxonomic study (review). Science 172:552.

14. Vishniac, W., and M. Santer. 1957. The thiobacilli. Bacteriol. Rev. 21:195-213. 